\title{
Likovno-umjetnička djela u nastavi vjeronauka
}

\author{
Dubravka Kuščević* \\ kuscevic@ffst.hr \\ https://orcid.org/0000-0002-4572-9933 \\ Marija Brajčićs* \\ mbrajcic@ffst.hr \\ https://orcid.org/0000-0002-2440-7724
}

\author{
https://doi.org/10.31192/np.18.3.7 \\ UDK: [37.091.3:7]:272-472 \\ 37.014.523:72/76 \\ Izvorni znanstveni rad / Original scientific paper \\ Primljeno: 15. srpnja 2020. \\ Prihvaćeno: 11. rujna 2020.
}

Umjetnički sadržaji u nastavi razvijaju estetske vrijednosti učenika te utječu na njihov doživljaj svijeta. Povezivanje odgojno-obrazovnih, vjeronaučnih i likovnumjetničkih sadržaja zahtijeva cjelovit, integrirani pristup. Korelacija je suvremen pristup nastavi, što podrazumijeva interdisciplinaran $i$ multidisciplinaran koncept u povezivanju nastavnih sadržaja. Suvremeni kurikulum vjeronauka prepoznaje važnost korelacije u nastavi. Uključivanje likovno-umjetničkih djela u nastavu vjeronauka može doprinijeti cjelovitom razvoju učenika te može omogućiti bolje uključivanje učenika u shvaćanje i doživljavanje vjerskih sadržaja. U ovom istraživanju provedenom na 199 učenika osnovnih $i$ srednjih škola željeli smo ispitati percepciju učenika o likovnom djelu u vjeronaučnoj nastavi. Rezultati su pokazali da učenici ponekad na nastavi promatraju umjetnička djela, a stariji učenici više od mladih vole promatrati umjetnička djela. Likovno-umjetnička djela u nastavi vjeronauka pozitivno utječu na lakše usvajanje vjeronaučnih sadržaja, te na kreativnost $i$ aktivnost učenika na satu. Likovno djelo u vjeronaučnoj nastavi također pozitivno utječe na korelaciju s hrvatskim jezikom i poviješću, što bolje uočavaju stariji učenici. Oni također bolje uočavaju da im promatranje umjetničkih djela pomaže u razumijevanju okoline u kontekstu vjere.

Ključne riječi: likovno-umjetnička djela, korelacija, učenici, vjeronauk.

\footnotetext{
* Doc. dr. sc. Dubravka Kuščević, Sveučilište u Splitu, Filozofski fakultet, Poljička cesta 35, HR21000 Split.

${ }^{* * *}$ Doc. dr. sc. Marija Brajčić, Sveučilište u Splitu, Filozofski fakultet, Poljička cesta 35, HR-21000 Split.
} 


\section{Uvod}

Uporabom likovno-umjetničkog djela u nastavi vjeronauka razvijamo kod učenika senzibilitet za umjetnički doživljaj svijeta. Razmišljanja koje se oblikuju korelacijom sadržaja likovne umjetnosti i vjeronauka obuhvaćaju estetsku i etičku dimenziju. Umjetnička djela u vjeronaučnoj nastavi daju učenicima uvid u nepregledan svijet ljudske kulture, a istovremeno omogućuju djeci i mladima shvaćanje kulture u svjetlu vjere da bi shvatili važnost kršćanske kulture u vremenu kojem pripadaju.

Kroz cijelu povijest čovjek je imao potrebu da se likovno izražava motiviran prirodnim impulsima ljudske psihe koji su bili magijski, religijski, osobni psihološki, estetski i praktični. S kojega god gledišta promatramo, bavljenje likovnošću imalo je pozitivan učinak na ljude. ${ }^{1}$

Umjetnost i umjetnička djela imaju značajan utjecaj na holistički razvoj djece $^{2}$ od predškolske dobi preko osnovnoškolskog pa sve do srednjoškolskog odgoja i obrazovanja. Glavne karakteristike suvremenog likovnog obrazovanja su interdisciplinarnost, interakcija i uključenost, interpretacija, povezivanje i korištenje novih medija. ${ }^{3}$ Umjetničko obrazovanje podrazumijeva poznavanje učeničkog razvoja i njegovih umjetničkih obilježja te nam pomaže razumjeti učenički likovni izraz. ${ }^{4}$

Likovna umjetnost u osnovnoj i srednjoj školi podrazumijeva uz stvaralaštvo učenika i prosudbu likovno-umjetničkih djela. Susret s likovnim djelom ne razvija samo kreativne sposobnosti djece, nego i perceptivne te receptivne sposobnosti, što znači aprecijacijske kompetencije. Tako suvremeno poučavanje likovne kulture pretpostavlja: (1) razvijanje likovnih kreativnih sposobnosti (produktivno) i (2) shvaćanje i razumijevanje likovne umjetnosti (perceptivno). ${ }^{5}$

Istraživanja pokazuju da u likovnom obrazovanju danas nije posvećeno dovoljno pozornosti razvijanju likovne aprecijacije. Zbog toga su učenici uskraćeni za znanja o tome kako promatrati umjetničko djelo, razumjeti ga te u njemu uživati. ${ }^{6}$ Umjetničko djelo možemo promatrati u nastavi različitih nastavnih

${ }^{1}$ Usp. Snježana ŠARANČIĆ, Dobrobiti likovnog stvaralaštva, Napredak, 154 (2014) 1-2, 91-104, 92.

${ }^{2}$ Usp. Blaženka BAČLIJA SUŠIĆ, Marijana ŽUPANIĆ BENIĆ, Preschool Teachers' Sensibility in Music and Visual Arts as a Foundation for Encouraging Creative Expression in Children, Croatian Journal of Education, 20 (2018) Sp. Ed. 3, 93-105, 93.

${ }^{3}$ Usp. Dennis ATKINSON, Art in Education: Identity and Practice, Dordrecht, Boston - London, Kluwer Academic publishers, 2002, 1-206, 167.

${ }^{4}$ Usp. Jerneja HERZOG, Creativity bilities of seventh grade pupils in Slovenian elementary schools, Nova prisutnost - časopis za intelektualna i duhovna pitanja, 15 (2017) 3, 363-375, 365.

${ }^{5}$ Usp. Matjaž DUH, Art appreciation for developing communication skills among preschool children, Center for Educational Policy Studies Journal, 6 (2016) 1, 71-94, 73.

${ }^{6}$ Usp. Matjaž DUH, Branka ČAGRAN, Miroslav HUZJAK, Kvaliteta i kvantiteta učenja likovne aprecijacije. Utjecaj školskih sustava na učeničku likovnu aprecijaciju, Croatian Journal of Education, 14 (2012) 3, 625-655, 643. 
predmeta, kao što su hrvatski jezik, povijest, glazbena i likovna kultura te vjeronauk pa je nužno dovesti učenike u kontakt s umjetničkim djelima.

Umjetničko djelo u nastavi vjeronauka može biti ključ za otkrivanje istine o ljudskome životu u svjetlu vjere. Likovna je umjetnost kroz povijest izrasla i na temeljima kršćanskoga navještaja evanđeoskih vrjednota stoga je nesumnjivo da vjeronaučna nastava može i mora biti značajno obogaćena likovnim sadržajima. Teologija i umjetnost, kao dio ljudske kulture, oduvijek su u povezanosti nastojale promicati Kristova otajstva da bi čovječanstvo vodile prema Izvoru - Kristovu otajstvu spasenja. Kršćanska likovna umjetnost mudrom otvorenošću je rasvjetljivala i usmjeravala ljudski pogled prema Kristu te nastojala promatrati Božje djelo u kontekstu čovjekova stvaralaštva. Povezivanje teologije i umjetnosti, posebno likovne umjetnosti, podrazumijeva često interdisciplinarno povezivanje u području kršćanske kulture. Veza između vjeronauka i umjetnosti s kršćanskim nadahnućem prirodna je i logična.

»Teologija i umjetnost, dvije su discipline koje oduvijek zauzimaju posebno mjesto i osobitu pozornost u čovjekovu životu, povezujući ga s misterioznim, ali uvijek privlačnim drugim svijetom. « ${ }^{7}$

Razumijevanje ikonografije u likovnoj umjetnosti doprinosi razumijevanju kršćanske kulture. Kršćanska sakralna umjetnost čini velik dio svjetske umjetničke baštine. Katolički vjeronauk u školama objašnjava i tumači kršćansku Objavu i nauk Katoličke crkve u svjetlu razuma i vjere da bi učenici upoznali i shvatili kršćansku kulturu kojoj pripadaju te da bi svoj život oblikovali u duhu kršćanske Objave.

"Katolički vjeronauk pridonosi općim ciljevima demokratske i humane škole, pogotovo što cjeloviti odgoj ljudske osobe promatra u svjetlu kršćanske antropologije i čovjeka koji je Božja slika, savršeno ostvarena u Isusu Kristu. ${ }^{8}$

Kurikulum katoličkoga vjeronauka za osnovnu i srednju školu u odgojnoobrazovnim ciljevima učenja i poučavanja navodi da bi katolički vjeronauk trebao omogućiti da svaki učenik:

»Poznaje i vrednuje ulogu i doprinos kršćanstva, osobito Katoličke crkve u kulturnome, obrazovnome, znanstvenome i gospodarskome razvoju i napretku hrvatskoga društva i zapadne civilizacije $u$ prošlosti i sadašnjosti, izgrađujući pritom vlastiti stav odgovornosti, poduzetnosti, sudioništva i solidarne humanosti u nastojanju oko izgradnje 'civilizacije ljubavi', «"

\footnotetext{
7 Vjekoslav HUZJAK, Teološka vizija umjetnosti isusovca Marijana Gajšaka, Obnovljeni život, 52 (1997) 6, 491-509, 491.

${ }^{8}$ MINISTARSTVO ZNANOSTI I OBRAZOVANJA, Odluka o donošenju kurikuluma za nastavni predmet Katolički vjeronauk za osnovne škole i gimnazije u Republici Hrvatskoj (NN 10/2019), https://narodne-novine.nn.hr/clanci/sluzbeni/2019_01_10_216.html (09.09.2020).

${ }^{9}$ Isto.
} 
Dakle, u kontekstu ljudske kulture, vjeronaučni sadržaji su važni i vrijedni, a obogaćeni korelacijsko obrazovnim sadržajima, omogućuju učenicima osvještavanje integracijske uloge kršćanske umjetnosti u prošlosti i sadašnjosti zapadne civilizacije. Shvaćajući ikonografijska značenja kršćanske umjetnosti učenici će bolje komunicirati i s vjeronaučnim sadržajima. Upravo u ovom segmentu odgojno-obrazovnih ciljeva učenja i podučavanja vjeronauka vidimo nužnost uporabe likovnog djela u nastavi vjeronauka da bi učenici razumjeli kulturni kontekst u koji su ukorijenjeni.

U suvremenom odgoju i obrazovanju naglašava se važnost likovne umjetnosti za kreativni i kognitivni razvoj djece i mladih općenito te razvoj njihovih evaluacijskih i komunikacijskih sposobnosti. Sukladno tome, važno je likovnu umjetnost uključiti u suvremene odgojno-obrazovne koncepte.

»Vrijednost podučavanja na sadržajima likovne umjetnosti u osnovnoj je školi višestruka jer poučavanje o likovnim sadržajima predstavlja ne samo kompleksno učenje, već i konkretno iskustvo doživljaja, shvaćanja i prihvaćanja svijeta zasnovanog na cjelokupnoj povijesti čovječanstva. (...) Iako likovno djelo u nastavi likovne kulture predstavlja odgovarajući likovni poticaj uz pomoć kojega bi se trebao pojasniti učenicima predviđeni likovni zadatak, svojom slojevitošću i otvorenošću likovno djelo može pridonijeti razvoju cjelokupnog dječjeg iskustva u spoznaji svijeta, što neosporno pridonosi intelektualnom, moralnom i estetskom razvoju učenika.« 10

Vjeronaučna nastava uvijek je komunikacijski proces u kojem se komunikacija odvija između učenika, vjeroučitelja i Kristova učenja, a uporaba sakralnih djela $u$ vjeronaučnoj nastavi jest snažan oblik neverbalne komunikacije koja omogućuje vizualni doživljaj, a time i interpretaciju.

„Vjeronaučna je nastava komunikacijski proces u čijem se središtu nalazi učenik i njegov odnos prema učitelju, a obojice prema Kristu. Konfesionalna vjeronaučna nastava pretpostavlja živi komunikacijski proces učenja o Kristu, zajedništva s Njime i usvajanja evanđeoskih vrednota, te nasljedovanje Isusa Krista u svakidašnjici.«"11

U nastavi vjeronauka značajno je povezivati asocijativnost verbalnih sadržaja s likovnim prikazima, odnosno likovno-umjetničkim sadržajima, poglavito ikonografijskim značenjima, što omogućava jedinstveno iskustvo, čime učenici dobivaju složeniju sliku vjere, umjetnosti i života. Umjetnost može postati mjesto sastajanja i susreta misterioznoga i lijepoga, tako da umjetničko djelo može biti kanal za propitivanje i razmišljanje. Vjeronaučni sadržaji nisu samo informacije i činjenična znanja. Navedeni sadržaji traže vlastito promišljanje i osoban odgovor.

\footnotetext{
${ }^{10}$ Dubravka KUŠČEVIĆ, Likovno-umjetnička djela u nastavi likovne kulture, Zbornik radova Filozofskog fakulteta u Splitu, 6-7 (2016) 43-54, 45-46.

${ }^{11}$ Jadranka GARMAZ, Živa komunikacija u vjeronaučnoj nastavi, Služba Božja - liturgijsko-pastoralna revija, 59 (2019) 1, 5-21, 20.
} 
»Unutar školskog programa vjeru se može definirati kao stav, nasuprot uskom shvaćanju vjere kao znanja određenih informacija i činjenica. U tom je kontekstu razrađena $\mathrm{i}$ operacionalizacija ciljeva te je kao globalni interkonfesionalni cilj određeno: postavljanje religioznih pitanja u životnim situacijama (svakodnevnim, konfliktnim, graničnim i sl.) i njihovo suprotstavljanje (interakcija) s odgovorima iz religiozne ili opće ljudske tradicije da bi se došlo do vlastitog odgovora. Pri tom se razlikuju tri dimenzije na kojima se postavlja religiozno pitanje: individualna, interpersonalna i razina normi u društvu. ${ }^{12}$

Likovna umjetnost i sama čini i individualni odgovor i društveni odjek te uvijek nužno potiče na promišljanje života, a različiti vizualni prikazi sakralnih tema mogu potaknuti na razmišljanje o različitim vjerskim pitanjima.

Proizlazi da je uspostavljanje korelacije između nastave vjeronauka i elemenata poučavanja likovne umjetnosti u segmentu promatranja likovno-umjetničkog djela logična i dapače nužna. Kroz povijest poučavanja vjerskih sadržaja umjetnost je uvijek bila jedna od značajnih čimbenika. Još od srednjeg vijeka u različitim vjerskim školama njeguje se likovni i glazbeni izraz u funkciji vjerskog obreda. Glazba, lirika i arhitektura trebali su na odgovarajući način - dekoriranjem crkvenih objekata i uzvišenom znakovitošću vjerskih obreda poslužiti religijskom nauku. Cijela povijest likovne umjetnosti od ranokršćanskog razdoblja do 19. st. ikonografijski je većinom religijskog sadržaja, te je zbog ove prirodne korelacije likovna djela lako i logično implemantirati u nastavu vjeronauka. Međutim, ključnu ulogu u uspostavljanju te korelacije svakako ima učitelj i nastavnik koji svojim znanjem i iskustvom na primjeren način može implementirati likovna djela u nastavu vjeronauka.

»U nastavnom procesu učitelj ima ulogu kreativnog posrednika između nastavnog gradiva i učenika. Međutim, nastavnik nije samo prijenosnik informacija, već je istodobno i osoba koja obrazovanje čini stvaralačkim činom. «13

U kurikulumu za nastavni predmet Katolički vjeronauk za osnovne škole i gimnazije u Republici Hrvatskoj govori se o važnosti interdisciplinarnog povezivanja vjeronauka s drugim školskim odgojno-obrazovnim područjima.

»Interdisciplinarna isprepletenost i povezanost Katoličkoga vjeronauka s drugim odgojno-obrazovnim područjima, međupredmetnim temama i ostalim nastavnim predmetima omogućava promicanje temeljnih kompetencija i vrijednosti kurikuluma, pridonosi cjelovitom odgoju učenika i razvoju njegovih generičkih i drugih kompetencija, osobito njegove osobne izgradnje i razvoja, njegove individualne i društvene odgovornosti te građanskih kompetencija te daje vlastiti prilog poticanju motivacije i aktivne suradnje i razvoju kritičkoga i stvaralačkoga mišljenja. ${ }^{14}$

\footnotetext{
${ }^{12}$ Jadranka GARMAZ, Sadržajni aspekti didaktike školskog vjeronauka, Crkva u svijetu, 40 (2005) 3, 279-302, 287.

${ }^{13}$ Marija BRAJČIĆ, Mara ŠUĆUR, Učestalost upotrebe likovno-umjetničkog djela u nastavi likovne kulture, Nova prisutnost, 17 (2019) 1, 59-73, 64.

${ }^{14}$ Ministarstvo znanosti i obrazovanja, Odluka o donošenju kurikuluma...
} 
Mogućnost povezivanja katoličkog vjeronauka s likovnom umjetnošću u kurikulumu vjeronauka naznačena je $u$ domeni $D$ te je predviđeno povezivanje u svim razredima osnovne i srednje škole sa sadržajima likovne umjetnosti.

»Povezanost s Likovnom kulturom očituje se i u domeni svih godišta Katoličkoga vjeronauka u kojoj učenik upoznaje kršćanske motive i utjecaj kršćanstva na hrvatsko društvo i na hrvatsku kulturu općenito. Tu posebno mjesto zauzima likovna umjetnost te graditeljstvo i arhitektura koji su sastavni dio likovne umjetnosti. ${ }^{15}$

Korelacijom nastavnih sadržaja učenici lakše povezuju znanja, razvijaju specifične vještine i navike te se lakše promiču odgojne vrijednosti u školi. Likovna umjetnost u svjetlu vjere biva nositeljica navještaja, ona može omogućiti učenicima uranjanje u otajstva vjere, a također može pružiti odgovor na mnoga pitanja iz povijesti kršćanstva te još više nadahnuti nova propitivanja o mjestu i ulozi kršćanstva u svijetu.

$\mathrm{Na}$ temelju navedenih promišljanja odlučili smo provesti istraživanje među učenicima osnovnih i srednjih škola da bismo doznali njihova razmišljanja o likovno-umjetničkim djelima u nastavi vjeronauka.

\section{Metodologija istraživanja}

\subsection{Cilj istraživanja}

Cilj istraživanja je ispitivanje percepcije učenika o likovno-umjetničkim djelima u nastavi vjeronauka u osnovnoj i srednjoj školi. Preciznije, u ovom istraživanju željeli smo ispitati:

a) Jesu li učenici naviknuti na promatranje likovno-umjetničkih djela u nastavi vjeronauka i jesu li skloni promatrati umjetnička djela na nastavi vjeronauka?

b) Utječe li promatranje likovno-umjetničkih djela na usvajanje vjeronaučnih sadržaja i lakše razmjenjivanje misli, iskustava i ideja učenika na satu vjeronauka?

c) Utječe li doticaj s likovno-umjetničkim djelom na bolju motivaciju i aktivnost učenika na nastavi vjeronauka?

d) Utječe li doticaj s likovno-umjetničkim djelom na kreativno stvaralaštvo učenika?

e) Mogućnosti povezivanja vjeronaučnih i ostalih sadržaja (povijest, hrvatski jezik, likovna kultura, likovna umjetnost) u nastavi vjeronauka $\mathrm{u}$ osnovnoj školi te usrednjoj školi?

${ }^{15}$ Isto. 
f) Pomaže li promatranje likovno-umjetničkog djela učenicima dubljem razumijevanju vjeronaučnog sadržaja i njegovoj primjeni u vlastitu životu?

Istraživanjem smo također htjeli utvrditi:

a) Postoji li povezanost između karakteristika učenika (uzrasta, spola, ocjene i interesa prema predmetu) i motivacije (aktivnosti) u dijelu nastave $s$ likovno-umjetničkim djelom?

b) Utječe li posjećivanje muzeja i galerija na motivaciju i aktivnost učenika te na bolje doživljavanje i shvaćanje likovno-umjetničkog djela?

\subsection{Uzorak ispitanika}

Korišteni uzorak istraživanja čini ukupno 199 učenika završnih razreda osnovnih i srednjih škola. Pri tome je omjer prema dobi podjednak, budući da ga čini $49 \%$ učenika osmih razreda i $51 \%$ učenika četvrtog razreda gimnazije, no čini ga veći broj učenica $(\mathrm{N}=124)$ nego učenika $(\mathrm{N}=75)$. Istraživanje je provedeno u tri osnovne škole i u tri gimnazije u Splitsko-dalmatinskoj županiji. Škole su izabrane slučajnim odabirom. U anketiranju su sudjelovali učenice i učenici koji pohađaju katolički vjeronauk kao izborni predmet. Anketiranje je provedeno u razdoblju od veljače do lipnja 2019. godine. Ispitanici su dobrovoljno sudjelovali u istraživanju te su samostalno odgovarali na anketni upitnik.

\subsection{Instrument}

Radi odgovaranja na istraživačka pitanja korišten je anketni upitnik kojeg su formirale autorice rada na osnovu poznavanja problematike vezane uz likovna umjetnička djela u nastavi likovne kulture te razgovora s vjeroučiteljima. Prvi dio upitnika sastoji se od pitanja o demografskim podacima sudionika (spol, razred) te biografskih podataka povezanih s tematikom istraživanja (npr. njihov afinitet prema nastavnom predmetu ili izloženost likovnim djelima u svakodnevnom životu).

Drugi dio upitnika čini ljestvica od 12 tvrdnji s kojima su sudionici morali izraziti svoje slaganje. Prije rješavanja im je predstavljena definicija pojma »likovno-umjetničko djelo« da bi kriterijska valjanost pitanja bila očuvana. Pitanjima se nastojalo obuhvatiti afinitet učenika prema uporabi likovnog djela u nastavi vjeronauka (Volim promatrati likovno-umjetnička djela na nastavi vjeronauka.), kao i njihova percepcija o utjecaju koji to ima na njihovu aktivnost na nastavi te usvajanje sadržaja (Lakše mi je dijeliti svoje misli, iskustva i ideje na nastavi vjeronauka kada je to povezano uz komentiranje likovno-umjetnič$k o g$ djela.). Zadatak sudionika na ovim česticama bilo je odgovaranje pomoću Likertove mjerne ljestvice s pet ponuđenih odgovora (1 - uopće se ne slažem; $5-\mathrm{u}$ potpunosti se slažem). 


\subsection{Metoda obrade podataka}

U analizi i obradi podataka izračunani su parametri deskriptivne statistike, uključujući frekvencije $(\mathrm{N})$, postotke (\%), aritmetičke sredine i standardne devijacije pojedinih odgovora na cjelokupnom uzorku, kao i skupinama unutar uzorka. Radi utvrđivanja postoje li razlike između pojedinih skupina na promatranim varijablama, korišten je t-test za nezavisne uzorke, sa stupnjem rizika od $1 \%$ i $5 \%$. Za ispitivanje povezanosti između pojedinih varijabli korišten je Pearsonov koeficijent korelacije (r). Svi podaci obrađeni su korištenjem programa IBM SPSS Statistics v.26.

\section{Rezultati i rasprava}

Da bismo odgovorili na istraživačka pitanja, prije svega je bilo potrebno doznati u kolikoj su mjeri učenici uopće naviknuti na promatranje likovno-umjetničkih djela na nastavi vjeronauka.

Odgovori učenika (slika 1) pokazuju da većina učenika ponekad ima uvršteno promatranju umjetničkih djela na nastavi vjeronauka, dok neki učenici na toj nastavi nažalost nikad ne vide umjetnička djela. Pri tome je važno naglasiti da se s porastom dobi smanjuje učestalost primjene likovnih djela na nastavi vjeronauka. Uspoređujući aritmetičke sredine učenika osnovnih i srednjih škola t-testom, uočava se statistički značajna razlika vidljiva u tablici 1.

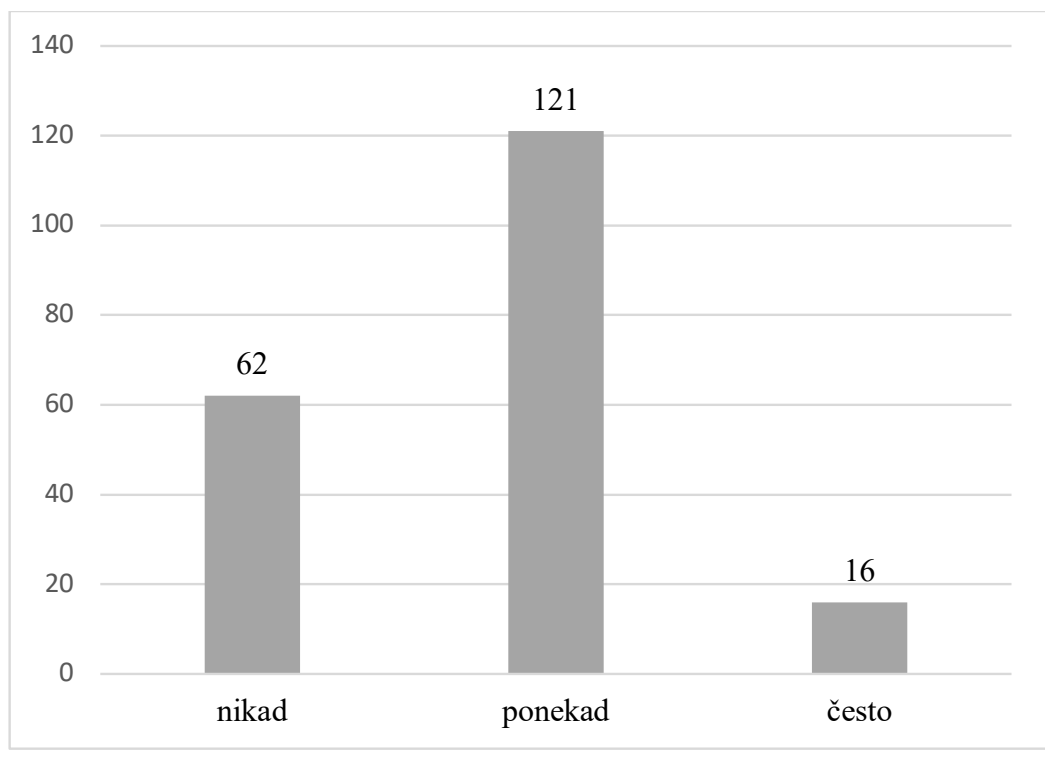

Slika 1. Učestalost promatranja likovnih djela na nastavi vjeronauka. 
Tablica 1. Razlika u učestalosti promatranja likovno-umjetničkih djela na nastavi vjeronauka

\begin{tabular}{|c|c|c|c|}
\hline $\begin{array}{c}\text { Koliko često promatrate likovna djela } \\
\text { na satu vjeronauka? }\end{array}$ & $\begin{array}{c}\text { Aritmetička } \\
\text { sredina }\end{array}$ & $\begin{array}{c}\text { Standardna } \\
\text { devijacija }\end{array}$ & t-test \\
\hline 8. razred OŠ & 1,97 & 0,507 & 5,066 \\
\hline 4. razred SŠ & 1,57 & 0,589 & $\mathrm{p}=0,00$ \\
\hline
\end{tabular}

Učenici u gimnaziji manje promatraju likovna djela nego učenici u osnovnoj školi. Stariji učenici imaju bolji mentalni kapacitet za shvaćanje umjetničkog djela s obzirom na poznavanje forme (znanja o likovnom jeziku), religijska znanja i mogućnost doživljavanja likovnog djela i zbog toga bi bilo važno da učenici u srednjoj školi više i češće promatraju likovno-umjetnička djela na nastavi vjeronauka da bi se promatranje likovnog djela s kršćanskim sadržajem u budućnosti moglo pretvoriti u religijski doživljaj koji se može shvatiti i analizirati.

Unutar ovoga pitanja bilo je važno provjeriti koliko su uopće učenici skloni upotrebi likovno-umjetničkih djela u nastavi vjeronauka. U prosjeku se pokazalo da učenici niti su skloni, niti neskloni promatranju umjetničkih djela na nastavi vjeronauka. To je dobiveno analizom odgovora na pitanja prikazanih $\mathrm{u}$ tablici 2.

Zadatak učenika bio je izražavanje svojega slaganja s navedenim tvrdnjama na ljestvici od 1 (uopće se ne slažem) do 5 (u potpunosti se slažem). U tablici su navedeni prosječni odgovori, kao i standardne devijacije za pojedino pitanje. Važno je naglasiti da je, unatoč prosječnoj ocjeni, ustanovljena statistički značajna razlika $(\mathrm{p}<0,05)$ u odgovorima učenika 8 . razreda osnovnih škola i učenika 4. razreda srednjih škola. Primjena t-testa pokazala je da su stariji učenici skloniji upotrebi likovno-umjetničkih djela na nastavi vjeronauka $\left(t_{1}=-2,216\right.$; $\left.\mathrm{t}_{2}=-2,298\right)$.

Tablica 2. Afinitet učenika prema upotrebi likovno-umjetničkog djela na nastavi vjeronauka

\begin{tabular}{|l|c|c|}
\hline \multicolumn{1}{|c|}{ Tvrdnje } & $\begin{array}{c}\text { Aritmetička } \\
\text { sredina }\end{array}$ & $\begin{array}{c}\text { Standardna } \\
\text { devijacija }\end{array}$ \\
\hline $\begin{array}{l}\text { Volim usvajati vjeronaučne sadržaje uz pomoć likovno- } \\
\text { umjetničkog djela. }\end{array}$ & 3,42 & 1,026 \\
\hline $\begin{array}{l}\text { Volim promatrati likovno-umjetnička djela na nastavi } \\
\text { vjeronauka. }\end{array}$ & 3,54 & 1,072 \\
\hline
\end{tabular}

Iz dobivenih rezultata možemo primijetiti da bi učenici završnih razreda srednjih škola, koji manje promatraju likovna djela na vjeronaučnoj nastavi, željeli imati više kontakta s umjetničkim djelima, što je i razumljivo jer imaju šire obrazovanje, interdisciplinarno znanje i više iskustva, što im svakako omogućava snažniji doživljaj likovnog djela. Stoga smatramo važnim uvažiti učenička razmišljanja vezana uz umjetnička djela na nastavi vjeronauka, o čemu 
bi vjeroučitelji prilikom koncipiranja pojedinih srednjoškolskih vjeronaučnih jedinica mogli razmišljati jer susret s likovno-umjetničkim djelom u nastavi ima niz prednosti u poučavanju.

»Ako je susret s likovnim umjetničkim djelom višedimenzionalan, jer je utemeljen na slojevitosti doživljaja samoga likovnoga djela, onda odabrano likovno djelo može promatraču, pored umjetničkog uživanja, pružiti i mnoge druge vrednote i sadržaje. «16

Razgovor s učenicima uz likovno djelo na vjeronaučnoj nastavi i vođenje njihove vizualno-likovne osjetljivosti prema kršćanskom smislu može uvijek na nov način uozbiljiti Kristovo otajstvo i potaknuti učenike na traženje istine. Naime, likovna umjetnost kršćanskoga sadržaja daje iskusiti neponovljivu novost kršćanske radosti koja izvor ima u jedinstvenom doživljaju spasenja.

Nadalje smo željeli ispitati utjecaj koji doticaj s likovno-umjetničkim djelom ima na različite elemente razmišljanja i ponašanja učenika. Odgovore na ova pitanja dobiveni su analizom odgovora na tvrdnje navedene u tablici 3, s kojima su morali izraziti svoje slaganje kako je opisano i u prethodnom pitanju.

Tablica 3. Utjecaj doticaja s likovno-umjetničkim djelom na razmišljanje i ponašanje učenika

\begin{tabular}{|l|c|c|}
\hline \multicolumn{1}{|c|}{ Tvrdnje } & $\begin{array}{c}\text { Aritmetička } \\
\text { sredina }\end{array}$ & $\begin{array}{c}\text { Standardna } \\
\text { devijacija }\end{array}$ \\
\hline $\begin{array}{l}\text { Lakše mi je dijeliti svoje misli, iskustva i ideje na nastavi } \\
\text { vjeronauka kada je to povezano uz komentiranje likovno- } \\
\text { umjetničkog djela. }\end{array}$ & 3,16 & 1,112 \\
\hline $\begin{array}{l}\text { Na nastavi vjeronauka uz pomoć likovno-umjetničkog djela } \\
\text { lakše usvajam vjeronaučni sadržaj. }\end{array}$ & 3,18 & 1,094 \\
\hline $\begin{array}{l}\text { Volim kada se mogu kreativno izraziti (crtati, slikati, } \\
\text { trodimenzionalno oblikovati) na poticaj likovno-umjetničkog } \\
\text { djela u nastavi vjeronauka. }\end{array}$ & 3,54 & 1,184 \\
\hline $\begin{array}{l}\text { Aktivnije i emocionalnije doživljavam vjeronaučni sadržaj ako } \\
\text { promatram likovno-umjetničko djelo vezano uz vjeronaučnu } \\
\text { temu. }\end{array}$ & 3,52 & 0,999 \\
\hline $\begin{array}{l}\text { Aktivno sudjelujem u nastavi vjeronauka kada su vjeronaučni } \\
\text { sadržaji pomoću likovno-umjetničkoga djelo zadani tako da } \\
\text { potiču moju kreativnost (npr. pretvori likovno djelo u strip...). }\end{array}$ & 3,80 & 1,068 \\
\hline
\end{tabular}

Promatrajući rezultate prikazane u tablici 3, moguće je zaključiti da doticaj s likovno-umjetničkim djelima na nastavi vjeronauka ima blago pozitivan utjecaj na lakše usvajanje vjeronaučnih sadržaja, te posebno na kreativnost i aktivnost učenika na satu. Međutim primjenom t-testa ponovno se uočava statistički značajna razlika u odgovorima učenika, ovisno o njihovoj dobi. Naime, u usporedbi s učenicima osnovnih škola, stariji učenici smatraju da lakše usvajaju

${ }^{16}$ Dunja PIVAC, Odgojna dimenzija likovnog djela, Svjedok - godišnjak Katehetskog ureda Splitsko-makarske nadbiskupije, 25 (2018) 12-19, 16. 
vjeronaučni sadržaj uz pomoć primjene likovno-umjetničkih djela na nastavi ( $\mathrm{t}$ $=-2,664 ; \mathrm{p}=0,008)$. Rezultat je očekivan jer stariji učenici imaju veću širinu u sagledavanju svijeta, razvijeniju estetsku osjetljivost za koju pretpostavljamo da su razvili tijekom školovanja te su spremniji za učenje iz više različitih izvora te se ne oslanjaju na samo jedan izvor učenja. Kod starijih učenika bolje je razvijena moć povezivanja i asocijativnost te uz pomoć simbola i slika mogu stvoriti bolje poveznice tijekom učenja te time i lakše usvojiti vjeronaučni sadržaj.

Isti trend uočen je i u poticanju kreativnog stvaralaštva učenika $(t=-2,512$; $p=0,013)$. Posebno kada su učenici, kao što rezultati pokazuju, iskazali da vole kada se mogu kreativno izraziti (crtati, slikati, trodimenzionalno oblikovati) na poticaj likovno-umjetničkog djela u nastavi vjeronauka. Danas se kreativnost nastoji razvijati u svim područjima života, a posebno u odgoju i obrazovanju djece i mladih.

»Sveukupni kurikul morao bi biti usmjeren na razvoj svakog subjekta u odgoju i obrazovanju, kako u razvijanju njegova znanja i sposobnosti tako i u poticanju njegove kreativnosti na raznim područjima. Poštivanje, oslobađanje, poticanje i razvijanje svih djetetovih sposobnosti preduvjet je kreativnosti s obzirom na njegovu inherentnu kreativnu sposobnost. ${ }^{17}$

Kreativnost podrazumijeva opažanje, promišljanje, doživljavanje i stvaranje. Kreativnost na najbolji mogući način upućuje na važnost stvaralaštva, o čemu je potrebno razmišljati kada se u vezu dovodi likovna kultura (likovno-umjetničko djelo) i vjeronaučni sadržaj, što učenici sami dobro uočavaju. Mogućnosti povezivanja vjeronauka i likovne umjetnosti u području kreativnosti mogu biti različite:

»Kreativnu prirodu djeteta i njegovu potrebu za izražavanjem i stvaranjem potrebno je poticati u nastavi vjeronauka. Gledati, misliti, povezivati, zaključivati, osjetiti i doživjeti - ciljevi su nastave Likovne kulture, ali i nastave Vjeronauka. $\ll^{18}$

Kreativnost u nastavi vjeronauka potrebno je posebno razvijati i njegovati, jer se kreativnost može doživljavati u različitim kontekstima:

»Kršćanska se kreativnost uvijek živi kao odraz vječnosti. U tome se svjetlu slobode, pouzdanja, nenavezanosti, rađaju novi putovi, načini, mijenjaju stajališta računajući na djelovanje Duha. Takva je kreativnost ponizna i radosna, jer se ne postavlja kao gospodarica, nego kao tražiteljica, oduševljena novim darovanim prostorima Prisutnosti.. ${ }^{19}$

\footnotetext{
${ }^{17}$ Jerneja HERZOG, Praćenje likovnog razvoja učenika četvrtih razreda - analiza stanja u hrvatskim osnovnim školama, Croatian Journal of Education, 20 (2018) 3, 973-1000, 973, https:// doi.org/10.15516/cje.v20i3.3041.

${ }^{18}$ Dubravka KUŠČEVIĆ, Likovna kultura i likovna kreativnost u nastavi vjeronauka, Svjedok godišnjak Katehetskog ureda Splitsko-makarske nadbiskupije, 25 (2018) 4-11, 4.

${ }^{19}$ Ivan ŠAŠKO, Liturgijska kreativnost suočena sa suvremenom obrednom »kreativnošću«, Živo vrelo - liturgijsko-pastoralni list za promicanje liturgijske obnove, 34 (2017) 2-7, 5.
} 
Promatranjem razlika u odgovaranju između učenica i učenika, pokazalo se da su učenice zadovoljnije nego učenici kada se mogu kreativno izraziti na poticaj likovno-umjetničkog djela na nastavi vjeronauka $(t=3,335 ; \mathrm{p}=0,001)$. Učenice su senzibiliziraniji za kreativno stvaranje uz poticaj likovnog djela $u$ nastavi. U vjeronaučnoj nastavi poticanje kreativnosti moguće je, pa i nužno, uz umjetničke sadržaje.

Također smo u istraživanju utvrdili da doticaj s likovno-umjetničkim djelom kod učenica značajno više utječe na lakše razmjenjivanje njihovih misli, iskustava i ideja na nastavi vjeronauka nego što je to slučaj kod muške populacije $(t=2,404 ; p=0,017)$, stoga bi u radu $\mathrm{s}$ učenicama vjeroučitelji mogli češće koristiti likovno-umjetnička djela. Ipak, glede utjecaja susreta s likovnoumjetničkim djelima na poboljšanje motivacije i aktivnosti učenika na nastavi vjeronauka nisu uočene nikakve razlike.

Nadalje, u ovom smo istraživanju željeli utvrditi mogućnosti povezivanja vjeronaučnih i ostalih nastavnih sadržaja uz pomoć korištenja likovnih djela u nastavi. Analiza prosječnih odgovora pokazala je da susret s likovno-umjetničkim djelima ne olakšava značajno usvajanje gradiva iz različitih predmeta (prosječna ocjena je 3 - niti se slažem niti se ne slažem). Međutim, moguće je primijetiti da učenici starijih razreda ipak više od učenika osnovnih škola smatraju da im susret s likovno-umjetničkim djelima na nastavi vjeronauka omogućuje lakše usvajanje gradiva u predmetima kao što su povijest ili hrvatski jezik (značajan t-test iznosi $\mathrm{t}=-2,567 ; \mathrm{p}=0,01)$. Ovi rezultati prikazani su u tablici.

Tablica 4. Razlika u povezivanju nastavnih sadržaja između učenika srednjih i osnovnih škola

\begin{tabular}{|l|c|c|c|c|}
\hline \multicolumn{1}{|c|}{ Tvrdnje } & Skupina & $\begin{array}{c}\text { Aritmetička } \\
\text { sredina }\end{array}$ & $\begin{array}{c}\text { Standardna } \\
\text { devijacija }\end{array}$ & t-test \\
\hline $\begin{array}{l}\text { Susret s likovno-umjetničkim djelom na } \\
\text { nastavi vjeronauka omogućava mi lakše } \\
\text { usvajanje gradiva u nastavnom predme- } \\
\text { tu Likovna kultura, Likovna umjetnost. }\end{array}$ & 8. razred OŠ & 2,88 & 1,067 & $-1,892$ \\
\cline { 2 - 5 } & 4. razred SŠ & 3,16 & 1,027 & $\mathrm{p}=0,06$ \\
\hline $\begin{array}{l}\text { Susret s likovno-umjetničkim djelom } \\
\text { na nastavi vjeronauka omogućava mi } \\
\text { lakše usvajanje gradiva u nastavnom } \\
\text { predmetu Povijest, Hrvatski jezik. }\end{array}$ & 8. razred OŠ & 2,72 & 1,129 & $-2,567^{*}$ \\
\cline { 2 - 5 } & 4. razred SŠ & 3,09 & 0,861 & $\mathrm{p}=0,01$ \\
\hline
\end{tabular}

Srednjoškolski učenici dobro uočavaju da im povezivanje vjeronaučnih nastavnih sadržaja omogućava obuhvaćanje cjelokupne stvarnosti, te im olakšava učenje i unapređuje znanje u nastavi hrvatskog jezika i povijesti, šteta što su samo djelomično vidjeli moguće poveznice vjeronauka s nastavom likovnih umjetnosti. »Takvim radom učenici lakše konstruiraju i povezuju znanja, razvijaju specifične vještine i navike te se lakše promiču odgojne vrijednosti.« ${ }^{20}$

\footnotetext{
${ }^{20}$ Jasmina VRKIĆ DIMIĆ, Sandra VIDIĆ, Korelacija i timski rad u nastavi - holistički pristup učenju i poučavanju, Acta Iadertina, 12 (2015) 2, 93-114, 94; https://hrcak.srce.hr/190135.
} 
Osim ispitivanja kako promatranje likovno-umjetničkih djela utječe na shvaćanje sadržaja iz drugih nastavnih predmeta, također smo željeli utvrditi pomaže li to učenicima u dubljem razumijevanju vjeronaučnog sadržaja i njegovoj primjeni u vlastitom životu. Kao i u prethodnom istraživačkom pitanju, pokazalo se da taj utjecaj nije značajan budući da su prosječni odgovori bili tek ponešto viši od 3 , što je vidljivo u tablici 5 . Primjena t-testa ipak pokazuje dodatnu distinkciju rezultata. Učenice više nego učenici smatraju da im primjena likovno-umjetničkog djela u nastavi pomaže u otkrivanju vjeronaučnog sadržaja $(t=2,442 ; p=0,015)$. Usto, srednjoškolci više od učenika osnovnih škola smatraju da im promatranje takvih djela na nastavi vjeronauka pomaže u razumijevanju svoje okoline $\mathrm{u}$ kontekstu vjere $(\mathrm{t}=-2,665 ; \mathrm{p}=0,008)$.

»Potaknuti odgovorima svojih učenika na poruke umjetničkih djela, nastavnici i vjeroučitelji ne bi smjeli propustiti važnu priliku odgojnog djelovanja dopuštajući učenicima rasprave o njihovim osjećajima, razmišljanjima i raspoloženjima, njihovu analizu, proradu, osvješćivanje i identifikaciju. $\ll^{21}$

Tablica 5. Utjecaj likovno-umjetničkog djela na primjenu vjeronaučnog sadržaja u životu

\begin{tabular}{|l|c|c|}
\hline \multicolumn{1}{|c|}{ Tvrdnje } & $\begin{array}{c}\text { Aritmetička } \\
\text { sredina }\end{array}$ & $\begin{array}{c}\text { Standardna } \\
\text { devijacija }\end{array}$ \\
\hline $\begin{array}{l}\text { Na nastavi vjeronauka uz pomoć likovno-umjetničkog djela } \\
\text { tražimo pravo značenje likovnog djela (otkrivamo vjeronaučni } \\
\text { sadržaj). }\end{array}$ & 3,17 & 1,118 \\
\hline $\begin{array}{l}\text { Promatrajući likovno-umjetničko-djelo u vjeronaučnoj nastavi } \\
\text { bolje razumijem poruke likovnog djela važne za moj život. }\end{array}$ & 3,31 & 1,055 \\
\hline $\begin{array}{l}\text { Promatrajući likovno-umjetničko djelo u vjeronaučnoj nastavi } \\
\text { bolje razumijem svijet u kojem živim u kontekstu svoje vjere. }\end{array}$ & 3,34 & 1,026 \\
\hline
\end{tabular}

Jedno od istraživačkih pitanja također je bilo utvrditi postoji li povezanost između različitih nastavnih aktivnosti, karakteristika učenika i njihove motivacije, tj. aktivnosti u nastavi uz likovno-umjetničko djelo. Rezultati prikazani u tablici 6 ukazuju na to da uzrast, spol i prošlogodišnja ocjena iz predmeta nisu povezani s aktivnosti učenika na satu. Međutim, sklonost prema vjeronauku kao predmetu je blago pozitivno povezana s angažmanom učenika prilikom usvajanja vjeronaučnog sadržaja $\left(\mathrm{r}_{1}=0,254, \mathrm{r}_{2}=0,328 ; \mathrm{p}<0,01\right)$. Drugim riječima, učenici koji više vole vjeronauk aktivnije sudjeluju na nastavi kada je ona popraćena prikazivanjem likovno-umjetničkih djela.

Nadalje, pitali smo se utječe li posjećivanje muzeja i galerija na motivaciju i aktivnost učenika te na bolje doživljavanje i shvaćanje likovno-umjetničkog djela. Promatrajući rezultate u korelacijskoj tablici možemo ustanoviti da to nije slučaj, budući da su korelacije male i neznačajne. Međutim zanimljivo je uočiti da postoji blaga, ali značajna pozitivna povezanost $(\mathrm{r}=0,149 ; \mathrm{p}<0,05)$

${ }^{21}$ Pivac, nav. dj., 19. 
između učestalosti posjećivanja muzeja, galerija ili izložbi radi upoznavanja s djelima likovne umjetnosti i stupnja sviđanja vjeronauka.

Tablica 6. Korelacijska matrica povezanosti karakteristika učenika i motivacije

\begin{tabular}{|l|c|c|c|c|c|c|c|}
\hline Korelacija (r) & Razred & Spol & Ocjena & Muzeji & Sviđanje & $\begin{array}{c}\text { Aktivnost } \\
\mathbf{1}\end{array}$ & $\begin{array}{c}\text { Aktivnost } \\
\mathbf{2}\end{array}$ \\
\hline Razred & 1 & $-0,147^{* *}$ & $0,159^{*}$ & $0,276^{* * *}$ & 0,019 & 0,068 & 0,003 \\
\hline Spol & & 1 & $-0,206^{* * *}$ & $-0,165^{*}$ & $-0,020$ & 0,012 & 0,049 \\
\hline Ocjena & & & 1 & 0,089 & 0,081 & $-0,020$ & 0,035 \\
\hline Muzeji & & & & 1 & $0,149^{*}$ & 0,098 & 0,050 \\
\hline Sviđanje & & & & & 1 & $0,254^{* * *}$ & $0,328^{* * *}$ \\
\hline Aktivnost 1 & & & & & & 1 & $0,476^{* * *}$ \\
\hline Aktivnost 2 & & & & & & & 1 \\
\hline
\end{tabular}

Legenda: * = značajna korelacija uz rizik od $5 \%$

$* *$ značajna korelacija uz rizik od $1 \%$

Između ostalog, iako su korelacije male, rezultati pokazuju da učenice imaju više ocjene iz vjeronauka nego učenici $(r=-0,206 ; p<0,01)$, kao i to da učenici $u$ srednjoj školi imaju bolje ocjene od učenika u osnovnoj školi $(r=0,159 ; \mathrm{p}<0,05)$. Također, možemo primijetiti da učenici srednje škole češće posjećuju muzeje i galerije nego učenici osnovnih škola $(r=0,276 ; p<0,01)$.

\section{Zaključak}

Tijekom osnovnoškolskog i srednjoškolskog razdoblja odgoja i obrazovanja komunikacija s likovno-umjetničkim djelima razvija kod učenika interes za područje ljudske kulture. Na taj način se učenici pripremaju za sudjelovanje u kulturnom životu i razumijevanju suvremene vizualne komunikacije. U kontaktu s likovno-umjetničkim djelima učenici razvijaju emocije, likovno razmišljanje, maštu i vizualnu memoriju, a također razvijaju svoj estetski ukus i etičke prosudbe. Promatranje likovno-umjetničkih djela na nastavi vjeronauka ne ostavlja učenike ravnodušnima već im omogućava promišljanje vjere kroz prizmu likovnih umjetnosti, što ističe i suvremeni vjeronaučni kurikulum.

Rezultati istraživanja su pokazali da većina učenika ponekad promatra umjetnička djela na nastavi vjeronauka pri čemu se, nažalost, s porastom dobi smanjuje učestalost primjene likovnih djela na vjeronaučnoj nastavi. Učenici su uglavnom ravnodušni prema promatranju likovno-umjetničkih djela na nastavi vjeronauka, ali ipak stariji učenici skloniji su tome, što bi im trebalo omogućiti na vjeronaučnoj nastavi. Doticaj s likovno-umjetničkim djelima na nastavi vjeronauka ima blago pozitivan utjecaj na lakše usvajanje vjeronaučnih sadržaja, te utječe na kreativnost i aktivnost učenika na satu i kod učenika i kod učenica. 
Učenice su, za razliku od učenika, zadovoljnije kada se mogu kreativno izraziti uz poticaj likovno-umjetničkog djela na nastavi vjeronauka. Također, doticaj s likovno-umjetničkim djelom kod učenica značajno više utječe na lakše razmjenjivanje njihovih misli, iskustava i ideja na nastavi vjeronauka nego što je to slučaj kod učenika.

Susret s likovno-umjetničkim djelima ne olakšava značajno usvajanje gradiva iz različitih predmeta. Međutim, moguće je primijetiti da učenici starijih razreda češće od učenika osnovnih škola smatraju da im susret s likovnoumjetničkim djelima na nastavi vjeronauka omogućuje lakše usvajanje gradiva u predmetima povijest ili hrvatski jezik, što svakako treba iskoristiti u nastavi prilikom prezentacije vjeronaučnih sadržaja.

U istraživanju smo utvrdili da umjetničko djelo nije presudno u dubljem razumijevanju vjeronaučnog sadržaja i njegovoj primjeni u vlastitom životu, ali učenice više nego učenici smatraju da im primjena likovno-umjetničkog djela u nastavi pomaže u otkrivanju vjeronaučnog sadržaja. Srednjoškolski učenici više od učenika osnovnih škola smatraju da im promatranje takvih djela na nastavi vjeronauka pomaže u razumijevanju svoje okoline u kontekstu vjere.

Uzrast, spol i prošlogodišnja ocjena iz predmeta nisu povezani s aktivnošću učenika na satu. Međutim, sklonost prema vjeronauku kao predmetu je blago pozitivno povezana s angažmanom učenika prilikom usvajanja vjeronaučnog sadržaja, odnosno učenici koji više vole vjeronauk aktivnije sudjeluju na nastavi kada promatraju umjetnička djela.

Istraživanje je također pokazalo da postoji pozitivna povezanost između učestalosti posjećivanja muzeja, galerija ili izložbi radi upoznavanja s djelima likovne umjetnosti i stupnja sviđanja vjeronauka.

Likovno-umjetnička djela možemo korelirati s nastavom vjeronauka i to na mnogo načina i na mnogo razina, što prepoznaju i učenici osnovnih i srednjih škola. Prilikom povezivanja predmeta od vjeroučitelja se zahtijeva bolja priprema u izvođenju nastavnih aktivnosti, ali učenici su ti koji $u$ tom procesu imaju važnu ulogu usvajajući nova znanja te povezujući ih s onima koja su prethodno naučili. Korelacijom u nastavi možemo zainteresirati učenike za rad, a sadržaje učiniti međusobno zanimljivima.

Sakralna likovna umjetnost u slavljenju vjere još od davnina ima zadaću uprisutniti događaj Božje objave vizualnim komuniciranjem, stoga likovnoumjetnička djela u nastavi vjeronauka značajno pridonose širenju kršćanskog navještaja među učenicima. 


\section{Dubravka Kuščević" - Marija Brajčić*** \\ Works of Art in the Teaching of Religious Education}

\section{Summary}

Connecting educational, religious and artistic content requires a comprehensive, integrated approach. Correlation in teaching represents a modern approach to teaching, which implies an interdisciplinary and multidisciplinary concept in connecting teaching content. The modern curriculum in religious education recognizes the importance of correlation in teaching. The inclusion of works of art in religious education can contribute to the overall development of pupils and can enable better understanding and perception of religious content. In this study, which involved 199 primary and secondary school pupils, we wanted to examine pupils' perception of the use of works or art in religious education. The results showed that pupils sometimes observe works of art during classes, and that older pupils prefer to observe works of art in comparison to younger pupils. Works of art used during religious education classes positively influence the adoption of religious content, and affect the creativity and activity of pupils in class. Girls, more so than boys, prefer when they can express themselves creatively in class with the use of a work of art and when they can share ideas and experiences based on artwork. The use of art during religious education positively affects the correlation with the Croatian language and history, especially among older pupils. Older pupils also stated that observing works of art helps them understand the environment in the context of faith.

Key words: correlation, pupils, religious education, visual arts.

(na eng. prev. Irena Zakarija-Grković)

\footnotetext{
* Dubravka Kuščević, PhD, Assis. Prof., University of Split, Faculty of Humanities and Social Sciences; Address: Poljička cesta 35, HR-21000 Split, Croatia; E-mail: kuscevic@ffst.hr.

${ }^{* * *}$ Marija Brajčić, PhD, Assis. Prof., University of Split, Faculty of Humanities and Social Sciences; Address: Poljička cesta 35, HR-21000 Split, Croatia; E-mail: mbrajcic@ffst.hr.
} 